\title{
Managing Complications Related to Multiple Supernumerary Teeth
}

\author{
Jongbin Kim
}

Department of Pediatric Dentistry, School of Dentistry, Dankook University

\section{Abstract}

One or two mesiodens are mostly common to the clinician. However, three mesiodens is rarely found and can cause complications such as orthodontic problems or interruptions of the adjacent teeth with more than 1 or 2 mesiodens.

Many factors cause irregularities in the permanent dentition. Mesiodens, especially in the anterior maxilla, can disturb the eruption of adjacent permanent teeth and cause diastemas, ectopic eruptions, root resorption, or the formation of dentigerous cysts. The early diagnosis of mesiodens is important for preventing such complications, and the timing of intervention should be based on their location and number. Periodic checkups and improved diagnostic devices make it easy to find mesiodens and associated complications.

In this case, 3 supernumerary teeth in the maxillary anterior region were affecting the eruption of the adjacent permanent incisors. To minimize complications and preserve the deciduous teeth, the three supernumerary teeth were extracted in 2 steps.

Since cone-beam computed tomography was not available, a brace wire was used to measure the depth of the mesiodens.

Key words : Supernumerary teeth, Depth check, Complication, Extraction

\section{Introduction}

More than $90 \%$ of supernumerary teeth occur in the maxilla; frequent locations include the vicinity of the maxillary central incisor (these are called mesiodens), maxillary lateral incisor, mandibular premolar, maxillary cuspid, and mandibular central incisor ${ }^{1)}$. There may be 1 (78.3\%), $2(21.1 \%)$, or, rarely, $3(<1 \%)$ supernumerary teeth $^{2)}$. If there are more than 3 supernumerary teeth, they are usually located in the mandible ${ }^{3)}$.

The timing of the surgical removal of supernumerary teeth is based on the formation of roots by the adjacent teeth. Removal is early when extracted before the $\mathrm{pa}^{-}$ tient is 7 years of age and delayed if older than 10 years; however, there is still controversy regarding the timing of removal ${ }^{4.5)}$.

This paper presents a case with 3 mesiodens in the maxillary central incisor region. To preserve the path of the maxillary permanent central incisors, the maxillary deciduous central incisors were left in place. The three mesiodens were removed in 2 steps. During the second surgery, the last mesiodens were separated to preserve the adjacent deciduous central incisor. Since cone-beam computed tomography (CBCT) was not available, a

Corresponding author : Jongbin Kim

Department of Pediatric Dentistry, School of Dentistry, 119 Dandaero, Dongnam-gu, Cheonan, 330-714, Korea

Tel: +82-41-550-0222 / Fax: +82-41-550-0118 / E-mail: ddsjbkim2879@gmail.com

Received April 25, 2014 / Revised May 13, 2014 / Accepted May 13, 2014 
brace wire was used to determine the exact depth of the mesiodens. Since the mesiodens were complicated by a diastema and ectopic eruption of the maxillary central incisor, orthodontic procedures were performed.

\section{Case Report}

A 5 and half year-old boy visited a private dental office for a periodic check-up. A panoramic view taken to check the location and eruption time of the permanent first molars and maxillary central incisors showed 3 mesiodens between the maxillary central incisors (Fig. 1 ). Both parents had a history of mesiodens, but no syndrome related to mesiodens. One mesiodens was located to the right of the maxillary central incisors and 2 to the left near the adjacent permanent central incisor. The left maxillary central incisor was dislocated upwards. As CBCT was not available, a conventional shifting technique with 2 intraoral X-rays was used to confirm a labial or palatal location. All three mesiodens were located in the palatal area (Fig. 2). In the first surgical pro- cedure, performed that month, the two mesiodens near the oral cavity were extracted (Fig. 3). Panoramic views were taken to evaluate the eruption of the adjacent teeth, especially the left maxillary central incisor, 5 and 9 months after the procedure (Fig. 4).

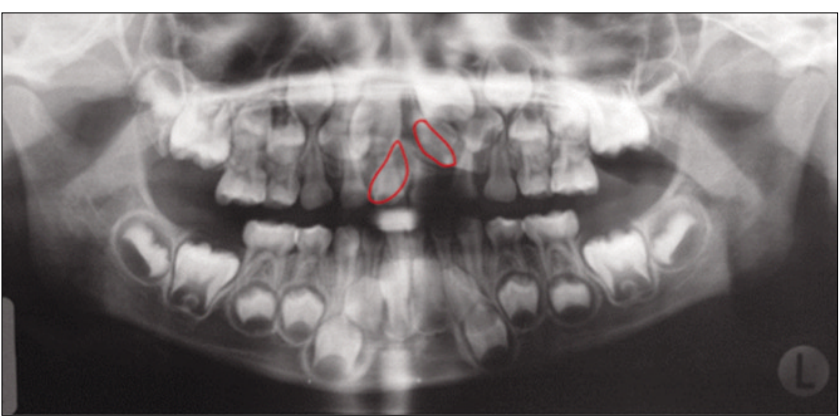

Fig. 1. Panoramic radiograph shows three mesiodens between the maxillary anterior teeth at first visit. The red circles are two mesiodens that are ready to extract at first operation.
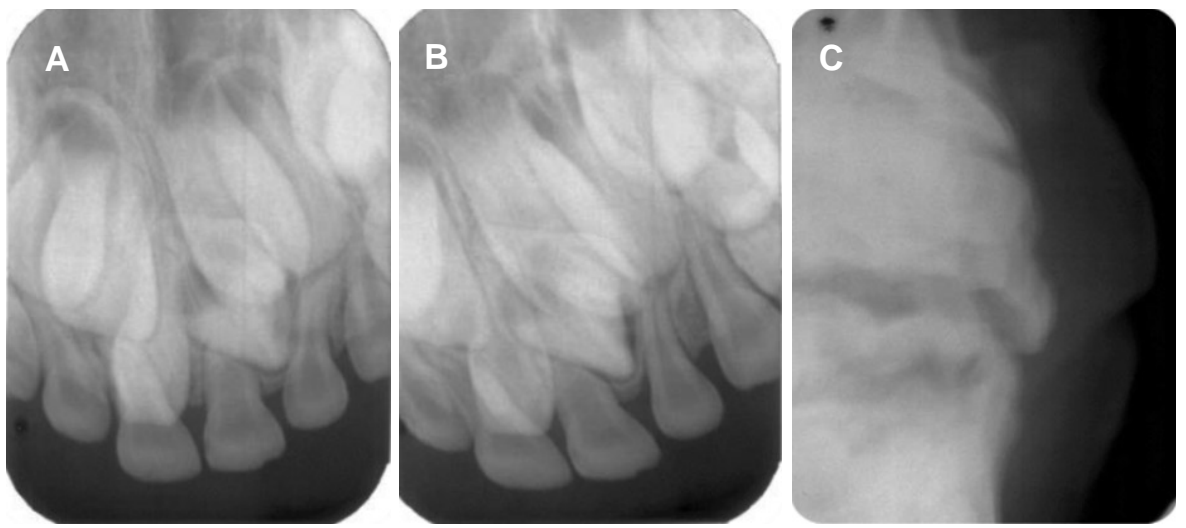

Fig. 2. (A) and (B) Two intraoral periapical radiographs for localization at first visit. (C) Occlusal view for AP position check. In this view, it is possible to determine that mesiodens are located at palatal portion.

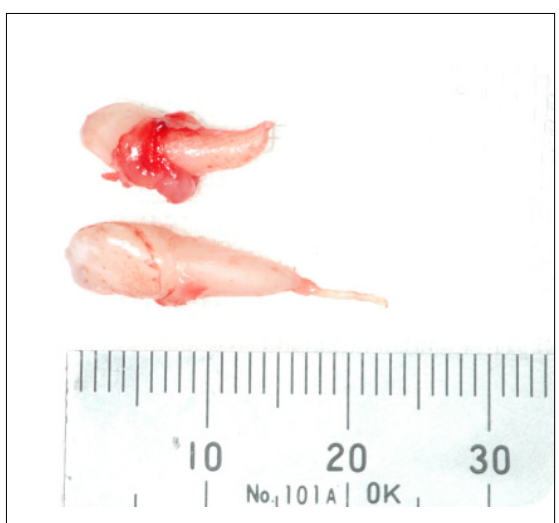

Fig. 3. Two conical shape mesiodens were extracted.
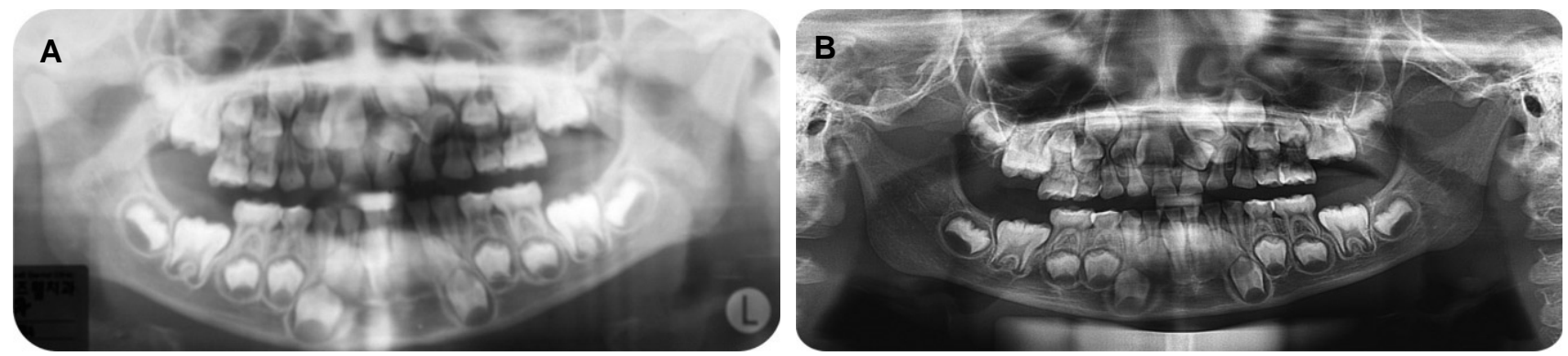

Fig. 4. (A) Panoramic view at 5 months later after surgery. (B) Panoramic view at 9 months later after surgery. 
When the patient was 6 years and 5 months old, the right maxillary central incisor was accelerated and the eruption of the left maxillary central incisor had started from the deep region; thus, the second extraction was performed. In this step, another X-ray with a brace wire was taken to measure the depth of the mesiodens (Fig. 5). As the maxillary deciduous central incisor remained on the left side, which might be good for preserving the path of the permanent central incisor, the remaining mesiodens were separated to facilitate removal and to preserve the adjacent deciduous incisor. This was checked with a periapical X-ray (Fig. 6). Additional periapical X-rays were taken after 7,13 , and 15 months to confirm the eruption path of the left maxillary permanent central incisor (Fig. 7).

When the patient was 7 years and 10 months old, the
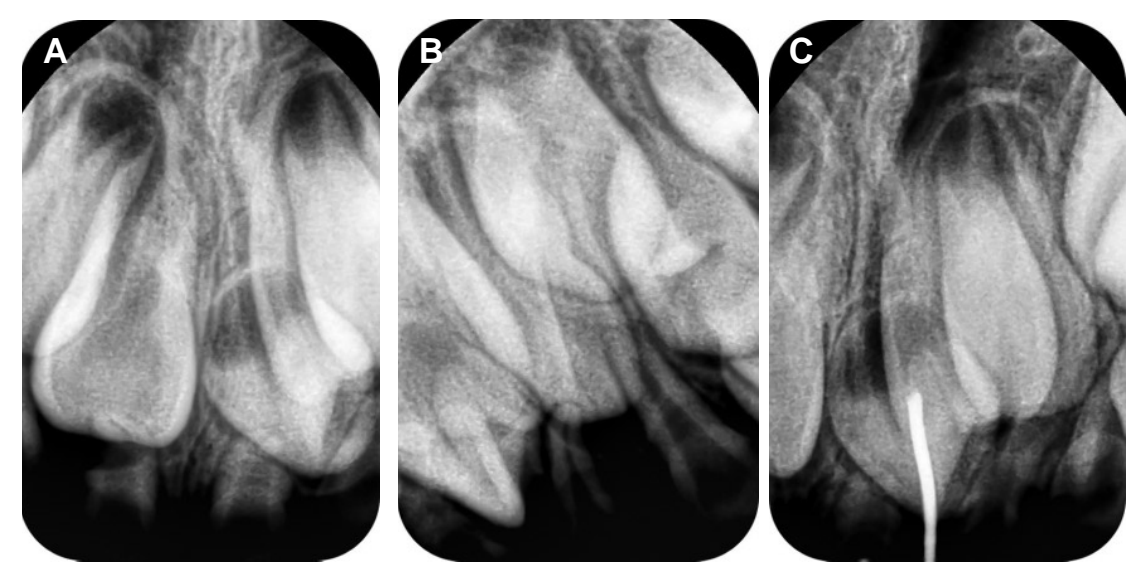

Fig. 5. (A) and (B) Two intraoral periapical radiographs for localization before second operation. (C) Brace wire was used for depth check of mesiodens.
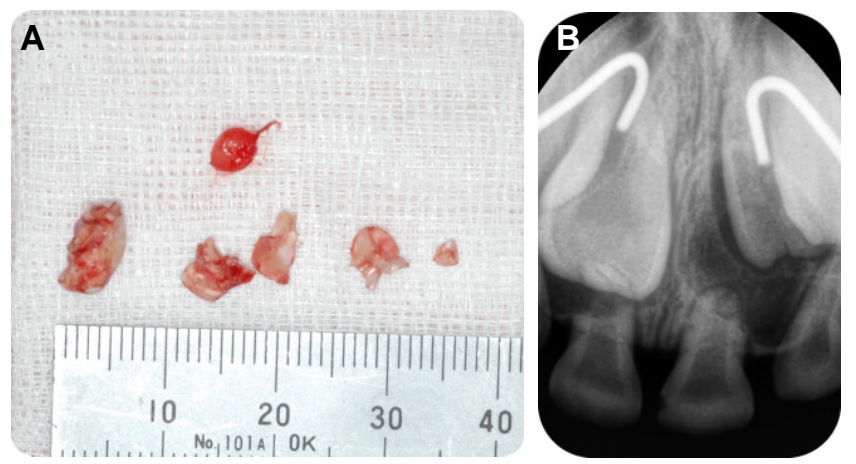

Fig. 6. (A) Separated mesiodens. (B) Intraoral periapical radiograph after second operation for check.

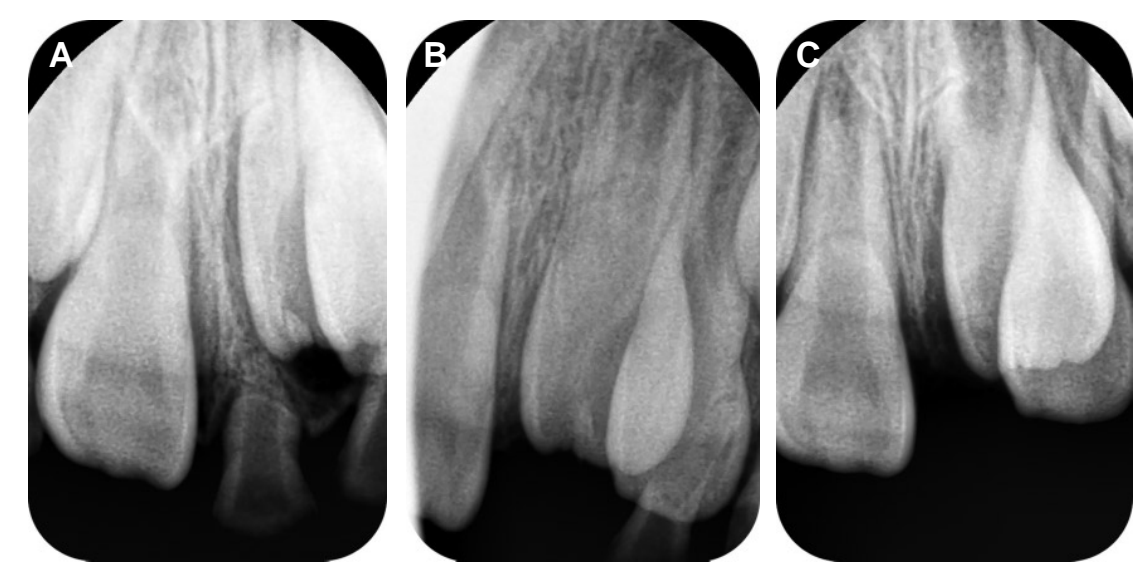

Fig. 7. (A) Intraoral periapical radiograph at 7 months later from second operation. (B) Intraoral periapical radiograph at 13 months later from second operation. (C) Intraoral periapical radiograph at 15 months later from second operation. 
right maxillary central incisor and left lateral incisor had erupted on the palatal side, while the left central incisor did not erupt and had no space to erupt. A panoramic view was taken to evaluate the path and space for the left maxillary central incisor (Fig. 8). At 8 years and 1 month of age, orthodontic treatment was performed to treat the anterior crossbite and make space for the left maxillary central incisor. At this time, intraoral photographs were taken (Fig. 9). Six months later, the crossbite of the right maxillary central incisor had been resolved, but orthodontic treatment was continued to allow eruption of the left maxillary central and lateral incisors (Fig. 10).

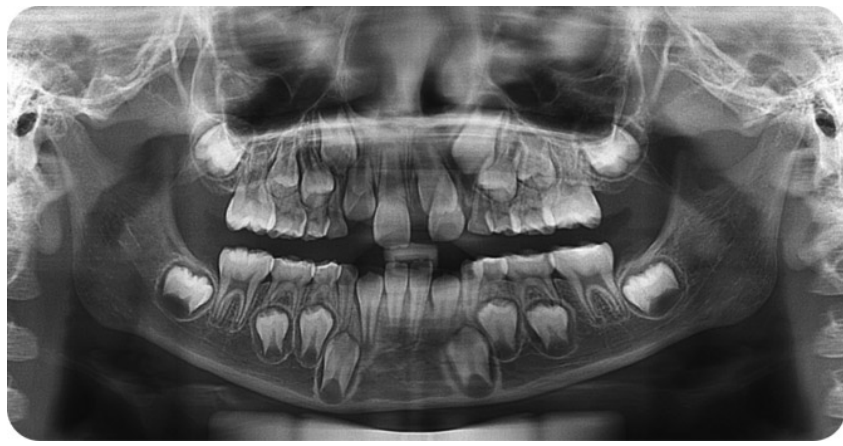

Fig. 8. Panoramic radiograph at 7 years and 10 months.

\section{Discussion}

Most supernumerary teeth are located in the maxillary region, and about $60 \%$ of these are impacted in the maxillary alveolar bone due to an inverted position. Consequently, they are unable to erupt. When located between the maxillary central incisors, a supernumerary tooth is called a mesiodens; these have an estimated prevalence of $0.15-3.18 \%$ and comprise almost $80 \%$ of supernumerary teeth ${ }^{6.7)}$. Kim et al. ${ }^{8)}$ reported that there was only 1 mesiodens in $63.2 \%$ of cases, 2 in $36.4 \%$, and 3 mesiodens in $0.4 \%$. This is similar to an earlier study by Kim et al. ${ }^{9}$ who found a single mesiodens in $81.1 \%$ of cases, 2 mesiodens in $18.9 \%$ of cases, and 3 mesiodens in no cases. Choi et al. ${ }^{2)}$ found a single mesiodens in $78.3 \%$ of cases, 2 mesiodens in $21.1 \%$ of cases, and 3 or more mesiodens in less than $1 \%$ of cases.

When there are 3 or more supernumerary teeth, they are usually found in the mandible and are strongly associated with cleidocranial dysplasia, Gardner syndrome, or cleft lip/palate ${ }^{3)}$. In 1990, Yusof ${ }^{(1)}$ reported non-syndrome multiple supernumerary teeth (i.e., cases with multiple supernumerary teeth without any systemic syndrome). In 2008, Hong et al. ${ }^{11)}$ reported a case with non-
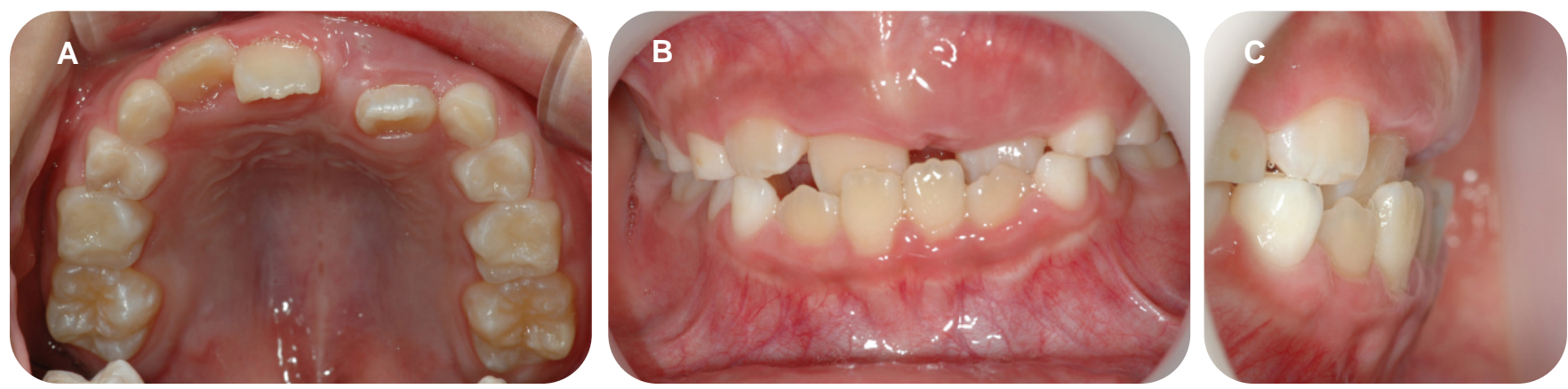

Fig. 9. Intraoral photographs at 8 years and 1 month before orthodontic treatment.
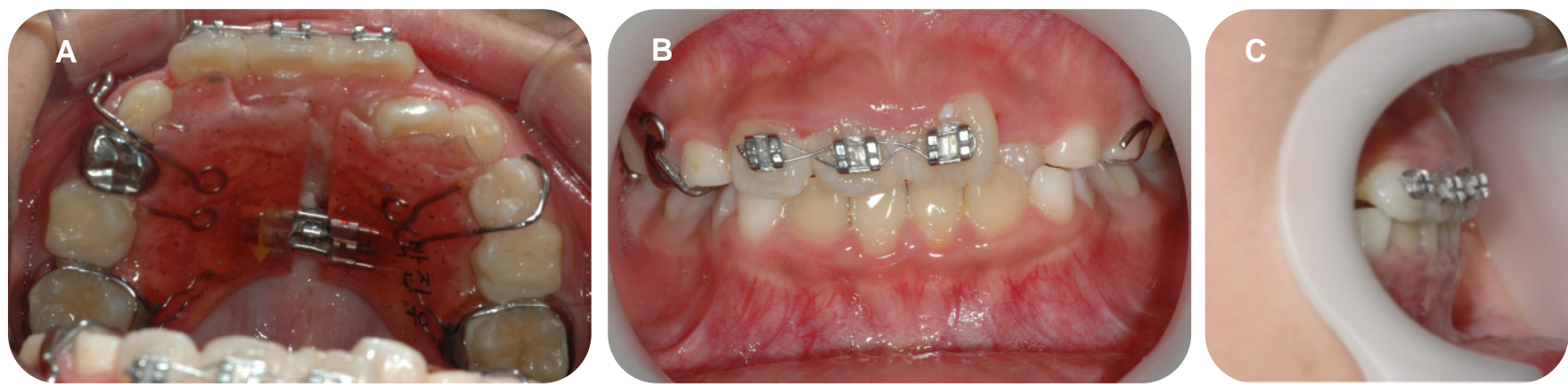

Fig. 10. Intraoral photographs at 8 years and 6 months. 
syndrome multiple supernumerary teeth in the central maxilla. They used a two-step surgical approach to remove 4 mesiodens to reduce damage to the adjacent permanent teeth.

In this study, a technique using another two X-rays (a panoramic view and an occlusal film) was used to determine the buccolingual location, eruption direction, number, shape, and other possible complications of the unerupted mesiodens. A panoramic view is usually favored for making diagnoses in the maxillofacial region. In nervous children, it is advantageous because it is quick and involves low radiation exposure. However, children have a small curvature radius in the maxillary region, which sometimes results in the overlap of adjacent structures, resulting in misleading information about mesiodens in the central maxillary region ${ }^{12}$. Therefore, a localization technique using 2 periapical $\mathrm{X}^{-}$ rays is needed to confirm the buccolingual location of mesiodens in children. Nevertheless, this two-dimensional technique has limitations because of the overlap of adjacent structures. To resolve these limitations, Choi et al. ${ }^{13)}$ used an appliance with a metal ball that was placed on the maxilla and took an X-ray to calculate the depth of the mesiodens.

In our case, three X-rays were used: 2 films for the localization technique and 1 film for a brace wire fixed to the cervical area of the maxillary central incisor to confirm the localization and measure the depth of the mesiodens.

Computed tomography (CT) is widely used because it provides three-dimensional information on the location of mesiodens, the distance between mesiodens and adjacent teeth, and the path for surgery. However, CT has some disadvantages: the total radiation dose is high and the equipment is large and very expensive ${ }^{14}$.

Mesiodens can give rise to a variety of complications, including diastemas, crowding, disturbed eruption or retention of teeth, delayed or abnormal root formation in permanent teeth, root resorption of adjacent teeth, and cysts $^{15-17)}$. Consequently, it is often difficult to decide whether they must be extracted surgically to reduce the chance of complications or observed periodically without extraction to give them a chance to erupt by themselves. The timing of the removal of any unerupted mesiodens is controversial. There are 2 methods for extracting mesiodens: early extraction before root formation of the permanent incisors before 7 years of age and late extraction after root formation of the permanent incisors after 10 years of age. Early removal of supernumerary teeth is better in terms of preventing complications, while the late removal of supernumerary teeth is better because the child's behavior is much easier to manage ${ }^{18)}$.

It is strongly suggested that the diagnosis of mesiodens be made as early as possible. The role of the pediatric dentist in the management of mesiodens is important because they tend to discover them earlier than other dentists. In addition, a two-step treatment is useful to allow spontaneous eruption and preserve a path for the permanent central incisor.

\section{Summary}

This case was not included in a previous study by the author because the patient was too young for a periapical X-ray. Consequently, that series did not include a case with 3 mesiodens. At that time, my patient was 41 months old and had no dental caries. During routine dental care, a panoramic view was taken at the age of 5.5 years to determine the timing of eruption of the permanent central incisors and first molar. At this time, three supernumerary teeth were found between the maxillary central incisors. To minimize complications, a two-step treatment was performed and a brace wire was used to measure the depth of the mesiodens at the second surgery. Despite these efforts, the case was complicated by an anterior crossbite. After 6 months of orthodontic treatment, the anterior crossbite of the central incisor was corrected. In summary, the pediatric dentist is the most important person responsible for managing mesiodens; if procedures are performed at the proper time, complications might be minimized and the results improved.

\section{References}

1. Zhu JF, Marcushamer M, King DL, et al. : Supernumerary and congenitally absent teeth: a literature review. J Clin Pediatr Dent, 20:87-95, 1996.

2. Choi BJ, Jang SC, Kim SO, et al. : Complications of supernumerary teeth on the maxillary anterior region. J Korean Acad Pediatr Dent, 30:515-518, 2003.

3. Gunduz K, Muglali M : Non-syndrome multiple supernumerary teeth: A case report. J Contemp Dent Pract, 8:81-87, 2007. 
4. Atwan SM, Turner D, Khalid A : Early intervention to remove mesiodens and avoid orthodontic therapy. Gen Dent, 48:166-169, 2000.

5. Alaçam A, Bani M : Mesiodens as a risk factor in treatment of trauma cases. Dent Traumatol, 25:2531, 2009.

6. Alberti G, Mondani PM, Parodi V : Eruption of supernumerary permanent teeth in a sample of urban primary school population in Genoa, Italy. Eur J Paediatr Dent, 7:89-92, 2006.

7. Kazanci F, Celikoglu M, Ceylan I, et al. : The Frequency and Characteristics of Mesiodens in a Turkish Patient Population. Eur J Dent, 5:361-365, 2011.

8. Kim SD, Lee SH, Lee NY, et al. : ThreeDimensional Evaluation of Impacted Mesiodens Using Dental Cone-Beam Computed Tomography in Korean Children and Adolescent. J Korean Acad Pediatr Dent, 40:149-156, 2013.

9. Kim JB, Kim JS, Park JE : The incidence of mesiodens. J Korean Acad Pediatr Dent, 34:646-650, 2007.

10. Yusof WZ : Non-syndrome multiple supernumerary teeth: literature review. J Can Dent Assoc, 56:147149,1990

11. Hong EH, Kim SO, Lee JH, et al. : Surgical Extraction of Multiple Supernumerary Teeth by Two-Stage Procedure. J Korean Acad Pediatr Dent
35:333-336, 2008

12. Ferguson JW, Evans RI, Cheng LH : Diagnostic accuracy and observer performance in the diagnosis of abnormalities in the anterior maxilla: a comparison of panoramic with intraoral radiography. $\mathrm{Br}$ Dent J, 173:265-271, 1992.

13. Choi HM, Han JW, Park HW, et al. : Quantitative localization of impacted mesiodens using panoramic and periapical radiographs. Imaging Sci Dent, 41:63-69, 2011.

14. Schmuth GP, Freisfeld M, Köster O, Schüller H : The application of computerized tomography (CT) in cases of impacted maxillary canines. Eur J Orthod, 14:296-301, 1992.

15. Tyrologou S, Koch G, Kurol J : Location, complications and treatment of mesiodentes-a retrospective study in children. Swed Dent J, 29:1-9, 2005.

16. Giancotti A, Grazzini F, Arcuri C, et al. : Multidisciplinary evaluation and clinical management of mesiodens. J Clin Pediatr Dent, 26:233237, 2002.

17. J Lustmann, L Bodner : Dentigerous cysts associated with supernumerary teeth. Int $J$ Oral Maxillofac Surg, 17:100-102, 1988

18. Yildirim G, Bayrak S : Early diagnosis of bilateral supplemental primary and permanent maxillary lateral incisors: a case report. Eur J Dent, 5:215-219. 2011. 


\title{
국문초록
}

\section{다수 과잉치로 인한 합병증 치료의 임상적 고찰}

\section{김종빈}

\author{
단국대학교 치과대학 소아치과학교실
}

임상가가 주로 접하게 되는 과잉치는 주로 1 2개인 경우가 거의 대부분을 차지한다. 드물게 보고되는 다수 과잉치는 $1 \sim 2$ 개의 과잉치의 경우보다 교정적인 합병증을 유발할 가능성이 높아지며, 인접치아의 손상가능성 또한 증가하게 된다.

상악 전치부에 호발 하는 과잉치는 상악 전치의 치간 이개, 맹출 장애, 전위, 인접 치아의 치근흡수 그리고 함치성 낭종의 형성 등 다양한 문제점들을 일으킬 수 있다. 따라서 조기에 발견하고 인접 구조물에 위해를 주지 않는 다면 이른 시기에 외과 적 적출술을 시행해 주는 것을 권한다.

최근에는 정기 검진과 방사선적 진단 장비의 발달로 이러한 대응이 원할 해 질 수 있는 여건이 마련되었다.

본 증례는 상악 전치부에 발생한 3개의 과잉치를 가능한 인접치의 손상을 줄이고, 유치의 잔존을 목표로 두 번에 걸쳐 발 거를 시행하였다. 개인 치과에서 시술을 하였기에 CBCT (Cone-Beam Computed Tomography) 와 같은 진단 장비의 도 움을 얻지 못하는 상황에서 브라스 와이어를 이용한 과잉치의 심도 확인법을 응용하였다.

주요어: 다수 과잉치, 심도 확인, 합병증, 발거 